\title{
Front Matter: Volume 11275
}

, "Front Matter: Volume 11275," Proc. SPIE 11275, Physics, Simulation, and Photonic Engineering of Photovoltaic Devices IX, 1127501 (1 April 2020); doi: $10.1117 / 12.2567550$

SPIE. Event: SPIE OPTO, 2020, San Francisco, California, United States 


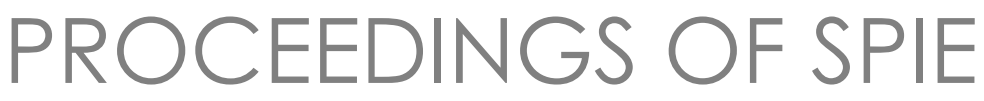

\title{
Physics, Simulation, and Photonic Engineering of Photovoltaic Devices IX
}

\author{
Alexandre Freundlich \\ Masakazu Sugiyama \\ Stéphane Collin \\ Editors
}

4-6 February 2020

San Francisco, California, United States

Sponsored and Published by

SPIE 
The papers in this volume were part of the technical conference cited on the cover and title page. Papers were selected and subject to review by the editors and conference program committee. Some conference presentations may not be available for publication. Additional papers and presentation recordings may be available online in the SPIE Digital Library at SPIEDigitalLibrary.org.

The papers reflect the work and thoughts of the authors and are published herein as submitted. The publisher is not responsible for the validity of the information or for any outcomes resulting from reliance thereon.

Please use the following format to cite material from these proceedings:

Author(s), "Title of Paper," in Physics, Simulation, and Photonic Engineering of Photovoltaic Devices $I X$, edited by Alexandre Freundlich, Masakazu Sugiyama, Stéphane Collin, Proceedings of SPIE Vol. 11275 (SPIE, Bellingham, WA, 2020) Seven-digit Article CID Number.

ISSN: 0277-786X

ISSN: 1996-756X (electronic)

ISBN: 9781510633131

ISBN: 9781510633148 (electronic)

Published by

SPIE

P.O. Box 10, Bellingham, Washington 98227-0010 USA

Telephone +1 3606763290 (Pacific Time) · Fax +1 3606471445

SPIE.org

Copyright (C) 2020, Society of Photo-Optical Instrumentation Engineers.

Copying of material in this book for internal or personal use, or for the internal or personal use of specific clients, beyond the fair use provisions granted by the U.S. Copyright Law is authorized by SPIE subject to payment of copying fees. The Transactional Reporting Service base fee for this volume is $\$ 18.00$ per article (or portion thereof), which should be paid directly to the Copyright Clearance Center (CCC), 222 Rosewood Drive, Danvers, MA 01923. Payment may also be made electronically through CCC Online at copyright.com. Other copying for republication, resale, advertising or promotion, or any form of systematic or multiple reproduction of any material in this book is prohibited except with permission in writing from the publisher. The CCC fee code is 0277$786 \mathrm{X} / 20 / \$ 18.00$.

Printed in the United States of America.

Publication of record for individual papers is online in the SPIE Digital Library.

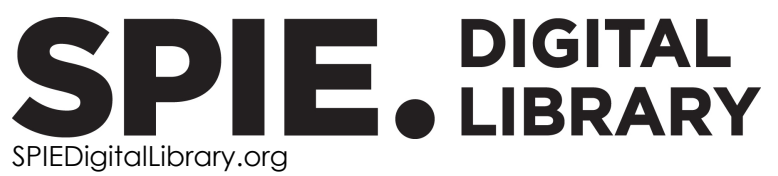

Paper Numbering: Proceedings of SPIE follow an e-First publication model. A unique citation identifier (CID) number is assigned to each article at the time of publication. Utilization of CIDs allows articles to be fully citable as soon as they are published online, and connects the same identifier to all online and print versions of the publication. SPIE uses a seven-digit CID article numbering system structured as follows:

- The first five digits correspond to the SPIE volume number.

- The last two digits indicate publication order within the volume using a Base 36 numbering

system employing both numerals and letters. These two-number sets start with 00, 01, 02, 03, 04,

05, 06, 07, 08, 09, OA, OB ... 0Z, followed by 10-1Z, 20-2Z, etc. The CID Number appears on each

page of the manuscript. 


\section{Contents}

vii Authors

ix Conference Committee

ADVANCES IN PHOTONIC DESIGNS AND MATERIAL DEVELOPMENTS FOR HIGH EFFICIENCY TANDEMS

$1127502 \quad$ Modeling and realization of photonic structures for silicon-based tandem solar cells (Invited Paper) [11275-1]

1127504 Design, modeling, and experimental results for CPV arrays built using heterogeneously integrated III-V micro-cells [1 1275-3]

HOT CARRIER SOLAR CELLS

1127507 Fabrication and optical characterization of ultrathin III-V transferred heterostructures for hotcarrier absorbers [11275-6]

11275 OA Advanced analysis for hot-carriers photoluminescence spectrum [1 1275-9]

DESIGN AND SIMULATION OF PEROVSKITES PV

$11275 \mathrm{OB} \quad$ Computational device optimization and parameter extraction for perovskite-based solar cells (Invited Paper) [11275-10]

$112750 \mathrm{C}$ Optical analysis and optimizations of semi-transparent triple cation perovskite solar cells for tandem applications [11275-11]

PEROVSKITES AND EMERGING PHOTOVOLTAICS

$11275 \mathrm{OH} \quad$ Controlling crystal growth of non-toxic Bismuth iodide (Bil3) semiconducting material for efficient photovoltaics [1 1275-16]

\section{CHARACTERIZATION OF SOLAR CELLS}

$112750 \mathrm{~J} \quad$ Non-contacting optical probing of photovoltaic device performance (Invited Paper) [11275-18] 
$11275 \mathrm{OL} \quad$ A comparison of the optoelectronic properties of high-efficiency polycrystalline and epitaxial $\mathrm{Cu}(\mathrm{In}, \mathrm{Ga}) \mathrm{Se}_{2}$ photovoltaic films [1 1275-20]

11275 OM Electron beam induced current characterization of solid-state dye sensitized solar cell [11275-21]

\section{CARRIER TRANSPORT IN QUANTUM/NANO-ENGINEERED SOLAR CELLS}

$112750 Q \quad$ Trade-off study on the radiative efficiency and carrier transport of multiple-quantum-well solar cells [1 1275-25]

11275 OR Dynamical view of charge transport and separation in nanojunctions [1 1275-26]

\section{ADVANCED LIGHT MANAGEMENT IN SOLAR CELLS}

11275 OS Nanostructures and design challenges in photovoltaic devices (Invited Paper) [11275-27]

11275 OT Design of photonic light-trapping structures for ultra-thin solar cells [1 1275-28]

11275 OU Benefits of Lambertian light distribution across widely deployed photovoltaic materials [11275-29]

IBSC AND QD SOLAR CELLS

$112750 X \quad$ Quasi-Fermi level splitting in InAs quantum dot solar cells from photoluminescence measurements (Invited Paper) [11275-32]

11275 OY Physics of the inter-subband transition in quantum-dot intermediate-band solar cell [1 1275-33]

\section{POSTER SESSION}

1127515 Propagation of the blackbody radiation in a periodic metamaterial [1 1275-40]

1127517 Optimization of solar cell packing models for flexible surfaces [11275-42]

1127518 Solar panels for the lunar base [11275-43]

11275 1A FDTD study of anti-reflective properties of photonic crystal slabs in silicon [1 1275-45]

11275 1B Enhancement of silicon nanowire micro-TEG using a plasmonic mid-IR absorber [11275-46] 
$11275 \mathrm{IE} \quad$ Plasmonic nanostructures for enhanced performance of microcrystalline silicon solar cells [11275-49]

Proc. of SPIE Vol. $112751127501-5$

Downloaded From: https://www.spiedigitallibrary.org/conference-proceedings-of-spie on 25 Apr 2023 Terms of Use: https://www.spiedigitallibrary.org/terms-of-use 
Proc. of SPIE Vol. 11275 1127501-6 Downloaded From: https://www.spiedigitallibrary.org/conference-proceedings-of-spie on 25 Apr 2023
Terms of Use: https://www.spiedigitallibrary.org/terms-of-use 


\title{
Authors
}

Numbers in the index correspond to the last two digits of the seven-digit citation identifier (CID) article numbering system used in Proceedings of SPIE. The first five digits reflect the volume number. Base 36 numbering is employed for the last two digits and indicates the order of articles within the volume. Numbers start with 00, 01, 02, 03, 04, 05, 06, 07, 08, 09, 0A, 0B...0Z, followed by 10-12, 20-2Z, etc.

\author{
Aboudiwan, Ahmed, 18 \\ Adhikari, Dipendra, 0J \\ Aeberhard, Urs, OB \\ Akef, Samar, 1B \\ Al-Jassim, Mowafak, OL \\ Altazin, Stephane, OB \\ Armour, Eric, 04 \\ Atlan, Fabien, 07 \\ Babcock, Sean J., OU \\ Baldwin, David, 04 \\ Beltako, K., OR \\ Bescond, Marc, OY \\ Bläsi, Benedikt, 02 \\ Blvelle, Balthasar, OB \\ Bodeux, R., OC \\ Burroughs, Scott, 04 \\ Carter, Jim, 04 \\ Cavassilas, Nicolas, OA, OR, OY \\ Charlton, Martin D. B., IA \\ Chen, Eric Y., OU \\ Chowdhury, Rahul, 17 \\ Collin, Stéphane, 07, 0C \\ Collins, Robert W., OJ \\ Coutancier, D., OC \\ Cutler, P. H., 15 \\ Delamarre, Amaury, OA, OY \\ Dhawan, Anuj, lE \\ Ekins-Daukes, Nicholas, OT \\ Esmaielpour, Hamidreza, OA \\ Fisher, Brent, 04 \\ Ghimire, Kiran, OJ \\ Gibelli, François, OA \\ Giteau, Maxime, 07, 0A \\ Guillemoles, Jean-François, 07, OA, OX, OY \\ Guthrey, Harvey, OL \\ Hassanen, Ahmed M., 1B \\ Hauser, Hubert, 02 \\ Hinzer, Karin, $0 Q$ \\ Hirst, Louise, OT \\ Höhn, Oliver, 02 \\ Honsberg, Christiana B., OU \\ Huang, Hsiang-Hung, $O Q$ \\ Irvin, Nicholas P., OU \\ Ishizuka, Shogo, OL \\ Jenatsch, Sandra, OB \\ Johnson, Andrew, OT \\ Jošt, M., OS \\ Junda, Maxwell M., OJ \\ Jutteau, S., OC
}

King, Richard R., OU

Kirsch, Christoph, OB

Knapp, Evelyne, OB

Kohlrausch, Emerson, OM

Koirala, Prakash, 0J

Kotulak, Nicole A., 04

Kovačič, M., OS

Krč, J., OS

Krishnan, Chirenjeevi, 1A

Kumar, Kamal, $1 \mathrm{E}$

Kumawat, Uttam K., IE

Lagoudakis, Pavlos G., 1 A

Lannoo, Michel, OR, OY

Leite, Marcos, OM

Lerner, P. B., 15

Lima, Camila F., OM

Lipovšek, B., OS

Lokar, Ž., OS

Lombez, Laurent, OA, OX

Lumb, Matthew P., 04

Marciniak, Malgorzata, 17, 18

Maskal, Leulaye, 18

Masroor, M., $\mathrm{OH}$

McClelland, A., $\mathrm{OH}$

McRae, J., $\mathrm{OH}$

Meitl, Matt, 04

Mercier, Thomas M., IA

Michelini, Fabienne, OR, OY

Miskovsky, N. M., 15

Miyashita, Naoya, 07

Molstad, E., OH

Mood, Thomas C., 04

Moore, James E., 04

Müller, Ralph, 02

Nakano, Yoshiaki, $0 Q$

Neukom, Martin, OB

Nguyen, Dac-Trung, OA

Ninawe, Akanksha, $1 \mathrm{E}$

Nishinaga, Jiro, OL

Nolde, Jill A., 04

Norman, Andrew, OL

Okada, Yoshitaka, 07, 0A, OX

Pearce, Phoebe, 0T

Podraza, Nikolas J., OJ

Pulwin, Ziggy, 04

Rahman, Tasmiat, $1 \mathrm{~A}$

Rao, P. M., $\mathrm{OH}$

Raoult, E., OC

Rivas, R., $\mathrm{OH}$ 
Rives, S., OC

Rousset, J., OC

Ruano, E., $\mathrm{OH}$

Ruhstaller, Beat, $\mathrm{OB}$

Ruppalt, Laura B., 04

Sayre, Larkin, OT

Schiller, Andreas, OB

Schmieder, Kenneth J., 04

Shaw, Peter J., IA

Shibata, Hajime, OL

Shoji, Yasushi, OX

Singleton, Christian, 18

Smole, F., OS

Sodabanlu, Hassanet, 07

Stepanova, Lidia, OB

Subedi, Biwas, OJ

Subedi, Indra, $0 \mathrm{~J}$

Suchet, Daniel, 07, OA, OY

Sugiyama, Masakazu, OQ

Sullivan, T., 15

Swillam, Mohamed A., 1B

Taha, Ali, 18

Tamaki, Ryo, OX

Topič, M., OS

Toprasertpong, Kasidit, $\mathrm{OQ}$

Tucher, Nico, 02

Uprety, Prakash, 0J

Vasconcellos, M.A. Z., OM

Wagner, Wolfgang, 04

Watanabe, Kentaroh, 07

Wilkins, Matthew, $O Q$

Yaiche, A., OC

Yan, T., $\mathrm{OH}$

Yan, Yanfa, OJ

Zuefle, Simon, OB 


\section{Conference Committee}

Symposium Chairs

Sailing He, KTH Royal Institute of Technology (Sweden) and Zhejiang University (China)

Yasuhiro Koike, Keio University (Japan)

Symposium Co-chairs

Connie J. Chang-Hasnain, University of California, Berkeley (United States)

Graham T. Reed, Optoelectronics Research Center, University of Southampton (United Kingdom)

Program Track Chairs

James G. Grote, Photonics Engineering Consultant (United States)

Shibin Jiang, AdValue Photonics, Inc. (United States)

Conference Chairs

Alexandre Freundlich, University of Houston (United States)

Masakazu Sugiyama, The University of Tokyo (Japan)

Stéphane Collin, Centre de Nanosciences et de Nanotechnologies (France)

Conference Program Committee

Urs Aeberhard, FLUXIM AG (Switzerland)

Kylie R. Catchpole, The Australian National University (Australia)

Gavin C. Conibeer, The University of New South Wales (Australia)

Olivier Durand, Fonctions Optiques pour les Technologies de l'information (France)

Jean-François Guillemoles, Institut Photovoltaïque d'lle-de-France (France) and NextPV LIA (Japan)

Karin Hinzer, University of Ottawa (Canada)

Seth M. Hubbard, Rochester Institute of Technology (United States)

Marina S. Leite, University of Maryland, College Park (United States)

Laurent Lombez, Institut Photovoltaïque d'lle-de-France (France) and NextPV LIA (Japan)

Marek Osiński, The University of New Mexico (United States)

Ian R. Sellers, The University of Oklahoma (United States)

Samuel D. Stranks, University of Cambridge (United Kingdom)

Robert J. Walters, Packet Digital (United States)

Peichen Yu, National Chiao Tung University (Taiwan) 
Session Chairs

1 Advances in Photonic Designs and Material Developments for High Efficiency Tandems

Alexandre Freundlich, University of Houston (United States)

Stéphane Collin, Centre de Nanosciences et de Nanotechnologies (France)

2 Hot Carrier Solar Cells

Kentaroh Watanabe, The University of Tokyo (Japan)

Seth M. Hubbard, Rochester Institute of Technology (United States)

3 Design and Simulation of Perovskites PV

Philip Schulz, National Renewable Energy Laboratory (United States)

Peichen Yu, National Chiao Tung University (Taiwan)

4 Perovskites and Emerging Photovoltaics

Marko Topic, University of Ljubljana (Slovenia)

5 Characterization of Solar Cells

Stéphane Collin, Centre de Nanosciences et de Nanotechnologies (France)

Karin Hinzer, University of Ottawa (Canada)

6 Carrier Transport in Quantum/Nano-Engineered Solar Cells

Urs Aeberhard, FLUXiM AG (Switzerland)

Matthew P. Lumb, U.S. Naval Research Laboratory (United States)

$7 \quad$ Advanced Light Management in Solar Cells

Nikolas J. Podraza, University of Toledo (United States)

Oliver Höhn, Fraunhofer-Institut für Solare Energiesysteme ISE (Germany)

$8 \quad$ IBSC and QD Solar Cells

Stephen M. Goodnick, Arizona State University (United States)

Ian R. Sellers, The University of Oklahoma (United States)

9 TPV and Other Emerging PV Devices

Abderraouf Boucherif, Université de Sherbrooke (Canada)

Ryo Tamaki, Research Center for Advanced Science and Technology (Japan) 